\title{
DUKUNGAN SOSIAL KELUARGA BERHUBUNGAN DENGAN KECEMASAN LANSIA YANG MENGALAMI NYERI SENDI DI POSYANDU LANSIA SEDAP MALAM KREMBANGAN SELATAN SURABAYA
}

\author{
Eny Astuti* \\ *STIKes William Booth Surabaya. Jl. Cimanuk No.20 Surabaya 60241 \\ enyastutiserang@gmail.com
}

\begin{abstract}
ABSTRAK
Lansia yang mengalami nyeri sendi akan merasakan ketakutan, kegelisahan serta sering mengalami masalah psikologis yang dapat menimbulkan kecemasan. Perasaan kecemasan dalam jangka waktu yang lama akan menimbulkan perasaan putus asa, depresi, menyalahkan diri dan fight or freeze. Individu yang mengalami perasaan kecemasan sangat membutuhkan dukungan sosial keluarga untuk mengurangi tekanan psikologis selama lansia mengalami ketakutan. Penelitian ini bertujuan untuk melihat Hubungan Dukungan Sosial Keluarga Dengan Kecemasan Pada Lansia Yang Mengalami Nyeri Sendi di Posyandu Lansia Sedap Malam Krembangan Selatan Surabaya. Rancangan penelitian ini menggunakan Metode Korelasi. Jumlah populasi dalam penelitian ini adalah seluruh lansia yang berada di Posyandu Lansia Sedap Malam berjumlah 56 lansia, pengambilan sampel menggunakan Simple Random Sampling dengan jumlah sampel 20 lansia yang terdiri dari 1 lansia pria (5\%) dan 19 lansia perempuan (95\%). Data yang dikumpulkan diperoleh melalui dua kuesioner yaitu kuesioner dukungan sosial keluarga dan kuesioner kecemasan. Data yang terkumpul dilakukan analisa uji Spearman dengan nilai $\mathrm{p}<0,05$ pada penelitian didapatkan hasil $\mathrm{p}=0,015$ dimana HO ditolak yang artinya ada hubungan dukungan sosial keluarga dengan kecemasan pada lansia. Dari hasil yang didapat diharapkan posyandu tetap mengadakan kegiatan sosial yang dapat meningkatkan hubungan sosial antara lansia dan pemberian penyuluhan kesehatan kepada masyarakat atau keluarga yang tinggal bersama lansia tentang pentingnya dukungan sosial keluarga untuk lansia.
\end{abstract}

Kata kunci : Dukungan Sosial Keluarga, Kecemasan, Lansia

\section{ABSTRACT}

Elderly who experience joint pain will feel fear, anxiety and often experience psychological problems that can cause anxiety. Feelings of anxiety over long periods of time will lead to feelings of despair, depression, self-blame and fight or freeze. Individuals who experience feelings of anxiety desperately need family social support to reduce psychological pressure as long as the elderly are afraid. This study aims to look at the Family Social Support Relationships With Anxiety in the Elderly Who Experienced Joint Pain at Elderly Posyandu Sedap Malam Krembangan Selatan Surabaya. The design of this study using the Correlation Method. The number of population in this study were all elderly in Elderly Posyandu of 56 elderly, sampling using Simple Random Sampling with sample amount 20 elderly consisting of 1 elderly man (5\%) and 19 elderly woman (95\%). The data collected were obtained through two questionnaires: Family Social Support Questionnaire and Anxiety Questionnaire. Data collected by Spearman test analysis with $p$ value $<0,05$ in research got result $p=0,015$ where $\mathrm{HO}$ rejected which mean there is relation of social support of family with anxiety at elderly. From the result, it is expected that posyandu will hold social activities that can improve social 
relationship between elderly and health counseling to community or family living with elderly about the importance of family social support for elderly.

Keywords: Family Social Support, Anxiety, Elderly

\section{Pendahuluan}

Menurut WHO tahun 1998 tentang kesejahteraan lanjut usia pada bab 1 pasal 1 ayat 2, yang dimaksud lanjut usia adalah seseorang yang mencapai usia 60 tahun keatas. Lansia adalah suatu proses alami yang tidak dapat dihindari dan masa tua merupakan masa hidup yang terakhir. Dimasa ini seseorang yang sudah tua akan mengalami beberapa kemunduran seperti kemunduran kemampuan kognitif sering lupa, kemunduran orientasi, serta sulit untuk menerima ide-ide baru. Secara biologis kemunduran yang terlihat sebagai gejala-gejala kemunduran fisik antar lain kulit mulai mengendur, timbul keriput, rambut beruban, gigi mulai ompong, pendengaran dan penglihatan mulai berkurang, mulai lelah, pergerakan mulai melambat (Priyoto,2015). Terganggunya penurunan kesehatan pada lansia ditunjukan dengan masalah yang menyangkut kehidupan biologis lansia, seperti nyeri sendi. Nyeri sendi adalah suatu akibat yang diberikan tubuh karena pengapuran atau akibat penyakit lain, salah satunya tingginya kadar asam urat atau kolesterol dalam tubuh. Penderita tidak mampu bergerak secara leluasa, berjalan merambat serta di ikuti rasa nyeri yang hebat sampai menangis, susah tidur, dan merasakan nyeri semua di seluruh tubuh. Hal ini menyebabkan lansia mengalami kecemasan yang tampak dari ungkapan lansia yang mengatakan saya takut tidak bisa ikut posyandu lansia, para lansia mengatakan takut akibat tidak bisa berjalan karena nyeri, takut nyeri ini akan akan bertambah parah dan akan menyebabkan kematian, takut menyusahkan keluarga karena terus membutuhkan supaya nyerinya berkurang, kecemasan adalah suatu respon terhadap situasi tertentu yang mengancam, dan merupakan hal yang normal terjadi menyertai perkembangan, perubahan fisologis atau biologis (Fitri Fauziah,2007). Orang yang mengalami kecemasan memiliki respons yang diberikan seseorang terhadap suatu objek yang belum jelas sebabnya ditandai dengan perasaan takut terjadi bahaya, ancaman pada dirinya atau orang lain, tidak berdaya dan tidak aman Dadang (2001). Kecemasan terkait langsung dengan keterbatasan dukungan sosial. Menurut Fesman dan Loester (2009), menjelaskan bahwa dukungan sosial merupakan prediktor bagi munculnya kecemasan dalam artian individu yang memperoleh dukungan sosial terbatas lebih berpeluang mengalami kecemasan, sementara individu yang memiliki dukungan sosial yang lebih baik tidak terlihat merasa cemas. Hal ini menunjukan akan pentingnya dukungan sosial dikalangan lansia untuk mengatisipasi masalah kecemasan tersebut dalam (Gurnasah, 2005). Dukungan sosial dapat diperoleh dari kelompok teman sebayanya, dukungan masyarakat dan dukungan keluarga. Berdasarkan studi pendahuluan yang dilakukan penulis ketika wawancara di Posyandu Lansia Sedap Malam Krembangan Selatan Surabaya dengan jumlah lansia sebanyak 56 orang diketahui bahwa 6 orang lansia diantaranya mempunyai keluhan nyeri sendi. Timbulnya nyeri sendi sering mucul di persendian terutama lutut dan pergelangan kaki. Lansia mengatakan bahwa rasa nyeri ini sering muncul secara tiba-tiba tanpa sebab yang jelas terlebih saat suhu udara cenderung dingin. Timbulnya rasa nyeri yang 
menyerang tiba-tiba ini maka para lansia biasanya menyimpan obat yang dapat meredam rasa nyeri walaupun pada kenyataannya rasa nyeri itu tidak segera hilang setelah minum obat. Kecemasan terhadap rasa nyeri ini juga ditunjukkan dengan selalu menyimpan air panas dalam termos untuk digunakan sebagai kompres jika rasa nyeri sendi menyerang tiba-tiba. Sedemikian tinggi rasa kecemasan terhadap datangnya rasa nyeri ini sehingga berbagai persiapan dilakukan agar dapat meredam rasa nyeri tersebut jika sewaktu-waktu muncul. Kondisi fisik yang menurun seperti pendengaran, penglihatan, maupun gerakan fisik dan usia semakin tua, sudah tidak dianggap dan tidak diperhatikan lagi oleh keluarganya. Hal ini sesuai dengan data yang penulis dapatkan dikeluarga yang mengatakan keluarga lansia jarang menemani lansia saat mengalami nyeri sendi karena keluarga sibuk dengan pekerjaanya, seringkali lansia ditinggal pergi dan berada diruamah sendirian sehingga keluaraga tidak tahu tentang keluhan yang dirasakan lansia selama ini. Hal inilah yang menjadi kecemasan lansia bahwa keadaan nyerinya tidak bisa diatasi dan dia merasa menanggung sendirian tanpa ada yang peduli terhadapnya. Faktor -faktor yang mempengaruhi kecemasan usia, gender, setatus ekonomi, karakteristik latar belakang yang lain, dukungan sosial keluarga. Kesejahteraan dan kualitas hidup yang baik dapat didukung dengan dukungan sosial salah satunya dengan dukungan sosial keluarga yaitu berupa dukungan informasional, dukungan penilaian, dukungan instrumental, dukungan emosional. Menurut jurnal Ayu (2014) dampak cemas dapat menyebabkan beberapa akibat yang berhubungan dengan kejiwaan. Dari berbagai faktor di atas, oleh karenanya agar tetap sehat dan sejahtera serta bermanfaat, perlu di dukung oleh lingkungan yang kondusif baik pada tingkat keluarga maupun masyarakat (Suardiman, 2001). Keberadaan dukungan sosial khususnya keluarga yang adekuat terbukti berhubungan dengan menurunya mortalitas, lebih mudah sembu dari sakit dan dikalangan kaum tua, fungsi kognitif, fisik dan kesehatan emosi (Ryan dan Austin dalam Friedman 1998)

World Health Organization (WHO) melaporkan bahwa 20\%, penduduk dunia terserang penyakit nyeri sendi. Dari studi tentang kondisi sosial ekonomi dan kesehatan lanjut usia yang dilaksanakan Komnas Lansia di 10 provinsi tahun 2006, di Indonesia diketahui bahwa penyakit terbanyak yang diderita oleh lansia adalah nyeri sendi yaitu sebanyak $69,39 \%$, setelah itu hipertensi, anemia, dan katarak (Komnas Lansia,2010). Prevalensi kecemasan di indonesia pada usia dewasa dan lansia sebanyak 50\% (Videback, 2011 dalam Subandi, 2013) Dari hasil studi pendahuluan menggunakan metode wawancara pada lansia di Posyandu Lansia Sedap Malam Krembangan Selatan diperoleh data tercatat ada 20 lansia yang aktif datang ke posyandu krembangan, ada 6 lansia yang gelisah, gemeter, adanya gangguan saat tidur, sakit kepala, berdebardebar, sulitnya berkonsentrasi dalam menghadapi suatu masalah dan berkeringat dingin. Kondisi lansia yang bertempat tingal di rumah tersebut, mereka kurang mendapatkan perhatian dari keluarga, hal ini disebabkan oleh kesibukan masingmasing. Dengan Kondisi fisik yang menurun seperti menderita penyakit, berkurangnya fungsi pendengaran, penglihatan, maupun gerak fisik dan usia semakin tua, sudah tidak dianggap dan diperhatikan lagi oleh keluarganya. Hal tersebut juga dapat menimbulkan keterasingan dan ketakutan pada lansia, sehingga lansia merasa sudah tidak berguna lagi dan hanya menyusahkan keluarganya saja. 
Lansia yang mengalami rasa sakit yang tidak sembuh-sembuh dan mengeluh terus menerus dengan rasa sakit yang dialaminya serta merasa tidak ada seseorang yang memperhatikan kondisinya akan mengalami masalah psikologis yang menimbulkan masalah kecemasan. Perasaan kecemasan dalam jangka waktu yang lama akan menimbulkan perasaan putus asa seperti perubahan tingkah laku, bicara cepat, meremas-remas tangan, berulang-ulang bertanya, tidak mampu berkonsentrasi atau tidak memahami penjelasan, tidak mampu menyimpan informasi yang diberikan, gelisa, keluhan badan, kedinginan dan telapak tangan lembab, rasa cemas, tegang, ketakutan, ganguan tidur, ganguan kecerdasan, perasaan depresi, gejala somatic, gejala sensorik, gejala kardiovaskuler, gejala pernapasan, gejala gastrointestinal, gejala urogenital, gejala vegetatif. Perasaan tidak berdaya dan tidak adekuat dapat terjadi, disertai rasa terasing dan tidak aman. Intensitas perasaan ini dapat meningkat atau menghilang tergantung pada kemampuan individu dan sumber-sumber pada suatu waktu tertentu. Dampak intensitas perasaan yang meningkat membantu individu memfokuskan untuk belajar, menyelesaikan masalah, berpikir bertindak, merasakan dan melindungi dirinya sendiri. Dukungan sosial pada penurunan kecemasan lansia yaitu meningkatkan angka harapan hidup sebagai dampak dari peningkatan kualitas kesehatan (Feriyanto,2013).

Kecemasan pada lansia dapat dikurangi atau dicegah dengan pemberian psikoterapi. Dapat diberikan melalui dukungan keluarga, Dukungan yang diberikan oleh keluarga sebagai sumber terdekat yang dimiliki lansia, yaitu memberikan nasehat, saran, bantuan dalam bentuk semangat, kehangatan personal, cinta, meringankan tugas lansia yang sedang stress, menemani lansia yang sedang stress, memberikan penghargaan positif. Dapat menimbulkan respon lansia merasa diakui keberadaannya, merasa diperhatikan, merasa dihargai, merasa tidak sendiri, memiliki rasa aman, serta memiliki tempat untuk sering berbagai keluh kesah yang dialami sehingga beban psikologis yang dirasakan akan terasa berat bila ditanggung sendiri, akan tetapi bila diceritakan akan terasa ringan menurut Priyanto (2013). Tingkat kecemasan lansia akan berkurang dan tingkat kesejahteraan tinggi karena mendapat dukungan sosial yang bersumber dari mereka yang memiliki kedekatan emosional, seperti anggota keluarga dan kerabat dekat (Gurnasa, 2011). Berdasarkan hal tersebut, dukungan sosial keluarga akan sangat membantu lansia yang kecemasan untuk meningkatkan kualitas hidup terkait dengan menurunnya tingkat kecemasan yang dialami lansia.

\section{Metode}

Rancangan penelitian yang digunakan dalam penelitian ini adalah Korelasional Yaitu menghubungkan 2 variabel yaitu Dukungan sosial kelarga dengan Lansia yang mengalami nyeri sendi. Berdasarkan waktunya, penelitian ini menggunakan desain cross sectional yakni jenis penelitian yang menekankan pengukuran hanya satu kali saja pada satu saat. Populasi dalam penelitian ini yaitu Seluruh Lansia yang mengalami nyeri sendi sebanyak 20 orang, kemudian ditentukan sampel sebanyak 20. dengan menggunakan Total sampling yaitu seluruh Populasi diambil sebagai sampel penelitian. Sebelum melakukan penelitian, peneliti memberikan inform consent kepada Lansia dengan kriteria sampel bersedia untuk diteliti dan sesuai dengan kriteria sampel untuk penelitian. Instrumen pengambilan data dengan menggunakan kuesioner. Untuk mengetahui Dukungan Sosial 
keluarga pada Lansia yang mengalami nyeri Sendi.

\section{Hasil Penelitian}

Hasil pengumpulan data tentang Hubungan Dukungan Sosial Keluarga dengan Kecemasan Lansia yang mengalami nyeri sendi di Posyandu Lansia Sedap Malam Krembangan Selatan Surabaya sebagai berikut.

3.1 Karakteristik Responden Berdasarkan Umur Responden

Tabel 3.1 Distribusi responden berdasarkan

\begin{tabular}{cccc}
\multicolumn{4}{c}{ Umur. } \\
\hline No & Umur & f & \% \\
\hline 1 & $60-65$ & 9 & $45 \%$ \\
2 & $66-70$ & 7 & $35 \%$ \\
3 & $71-75$ & 3 & $15 \%$ \\
4 & $76-80$ & 1 & $5 \%$ \\
\hline \multicolumn{2}{l}{ total } & 20 & $100 \%$ \\
\hline
\end{tabular}

Sumber Data : Kuesioner Penelitian

Berdasarkan tabel 3.1 dapat diketahui bahwa terbanyak responden dengan Umur 60-65 tahun, yaitu sebanyak 9 responden $(45 \%)$

3.2 Karakteristik Responden berdasarkan Pendidikan

Tabe1 3.2 Karakteristik Responden Berdasarkan Pendidikan

\begin{tabular}{cccc}
\hline No & Pendidikan & f & \% \\
\hline 1 & Tidak Sekolah & 2 & $10 \%$ \\
2 & SD & 12 & $60 \%$ \\
& SMP & 3 & $15 \%$ \\
3 & SMA & 2 & $10 \%$ \\
4 & PT & 1 & $5 \%$ \\
\hline & Total & 20 & $100 \%$ \\
\hline
\end{tabular}

Sumber Data : Kuesioner Penelitian

Berdasarakan Tabe1 3.2 di atas menunjukkan bahwa terbanyak responden berpendidikan SD yaitu sebanyak 12 responden $(60 \%)$.

3.3 Karakteristik Responden berdasarkan Paritas.
Tabe1:3.3 .Karakteristik Responden

Berdasarkan Paritas.

\begin{tabular}{|c|c|c|c|}
\hline No & Paritas & $\mathbf{f}$ & $\%$ \\
\hline 1 & Tidak Punya anak & - & $0 \%$ \\
\hline 2 & 1 & 4 & $20 \%$ \\
\hline 3 & $2-3$ & 3 & $15 \%$ \\
\hline 5 & $>3$ & 13 & $65 \%$ \\
\hline \multicolumn{2}{|r|}{ Total } & 20 & $100 \%$ \\
\hline
\end{tabular}

Sumber Data : Kuesioner Penelitian

Berdasarkan tabel 3.3 dapat diketahui bahwa bahwa terbanyak responden punya $>3$ anak, yaitu sebanyak 13 responden (65 $\%)$.

3.4 Karakteristik Responden berdasarkan Pekerjaan

Tabe1 3.4.Karakteristik Responden Berdasarkan Pekerjaan

\begin{tabular}{llcc}
\hline No & Pekerjaan & f & \% \\
\cline { 1 - 2 } 1 & Bekerja & 6 & $30 \%$ \\
2 & Tidak bekerja & 14 & $70 \%$ \\
\hline & Total & 20 & $100 \%$ \\
\hline
\end{tabular}

Sumber Data : Kuesioner Penelitian

Berdasarkan tabel 3.4 dapat diketahui bahwa sebagian besar responden tidak bekerja yaitu 14 responden (70 \%)

3.5 Karakteristik Responden berdasarkan Status Perkawinan

Tabe 1 3.5.Karakteristik Responden Berdasarkan Status Perkawinan

\begin{tabular}{llcl}
\hline No & Status Perkawinan & f & \% \\
\cline { 1 - 2 } 1 & Menikah & 6 & $30 \%$ \\
2 & Duda/Janda & 14 & $70 \%$ \\
\hline & Total & 20 & $100 \%$ \\
\hline
\end{tabular}

Sumber Data : Kuesioner Penelitian

Berdasarkan tabel 3.5 dapat diketahui bahwa sebagian besar responden Duda/Janda yaitu 14 responden $(70 \%)$

3.6 Karakteristik Responden berdasarkan Status Tempat Tinggal.

Tabe1 3.6.Karakteristik Responden

Berdasarkan Status Tempat Tinggal

\begin{tabular}{|c|c|c|c|}
\hline No & Status Tinggal & f & $\%$ \\
\hline 1 & Sendiri & 5 & $25 \%$ \\
\hline 2 & Bersama Keluarga & 15 & $75 \%$ \\
\hline & Total & 20 & $100 \%$ \\
\hline
\end{tabular}

Sumber Data : Kuesioner Penelitian 
Berdasarkan tabel 3.6 dapat diketahui bahwa sebagian besar responden Tinggal bersama Keluarga $=15$ responden $(75 \%)$

3.7 Karakteristik Responden berdasarkan Pekerjaan

Tabe1 3.7.Karakteristik Responden Berdasarkan Jenis Kelamin

\begin{tabular}{|c|c|c|c|}
\hline No & Jenis Kelamin & f & $\%$ \\
\hline 1 & Laki-Laki & 1 & $5 \%$ \\
\hline 2 & Perempuan & 19 & $95 \%$ \\
\hline & Total & 20 & $100 \%$ \\
\hline
\end{tabular}

Sumber Data : Kuesioner Penelitian

Berdasarkan tabel 3.7 dapat diketahui bahwa sebagian besar responden tidak bekerja yaitu 14 responden $(70 \%)$

3.8 Dukungan Sosial Keluarga Tabel 3.8 Distribusi Frekuensi Dukungan Sosial Keluarga .

\begin{tabular}{cccc}
\hline No & Kategori & $\mathbf{f}$ & \% \\
\hline 1 & Baik & 6 & $30 \%$ \\
2 & Cukup & 9 & $45 \%$ \\
3 & Kurang & 5 & $25 \%$ \\
\hline & Total & 20 & $100 \%)$ \\
\hline
\end{tabular}

Sumber Data : Kuesioner Penelitian

Dari tabel 3.8 di atas menunjukkan bahwa sebagian besar yaitu sebanyak 9 lansia (45\%) responden mendapatkan dukungan sosial keluarga cukup.

3.9 Kecemasan Pada Lansia

Tabel 3.9 Distribusi Frekuensi Dukungan Sosial Keluarga .

\begin{tabular}{cccc}
\hline No & Kategori & $\mathbf{f}$ & $\mathbf{\%}$ \\
\hline 1 & Tdk Cemas & 0 & $0 \%$ \\
2 & Ringan & 15 & $75 \%$ \\
3 & Sedang & 5 & $25 \%$ \\
4 & Berat & 0 & $0 \%$ \\
\hline & Total & 20 & $100 \%)$ \\
\hline
\end{tabular}

Sumber Data : Kuesioner Penelitian

Berdasarkan tabel 5.9 dapat diketahui bahwa sebagian bersar yaitu sebanyak 15 lansia $(75 \%)$ responden kecemasan ringan, dan hanya 5 lansia (25\%) yang mengalami kecemasan sedang.
3.10 Hubungan Dukungan Sosial Keluarga dengan Kecemasan.

Tabel 3.10 tabel tabulasi silang antara dukungan sosial keluarga dengan kecemasan nyeri sendi pada lansia di Posyandu Sedap Malam Krembangan Selatan Surabaya

\begin{tabular}{lllll}
\hline No & $\begin{array}{c}\text { Dukungan } \\
\text { sosial } \\
\text { keluarga }\end{array}$ & \multicolumn{2}{c}{ Kecemasan lansia } & Jumlah \\
\hline 1. & Baik & $6(30 \%)$ & - & $6(30 \%)$ \\
2. & Cukup & $6(30 \% 0$ & $3(15 \%)$ & $9(45 \%)$ \\
3 & Kurang & $3(15 \%)$ & $2(10 \%)$ & $5(25 \%)$ \\
\hline Jumlah & $15(75 \%)$ & $5(25 \%)$ & $20(100 \%)$ \\
\hline \multicolumn{3}{l}{ Uji spearman $\mathrm{p}=0,015$} \\
\hline
\end{tabular}

Dari tabulasi silang diatas tampak bahwa terdapat 3 lansia responden (15\%) yang kecemasan ringan dengan dukungan sosial keluarga kurang, dan hanya 2 lansia responden $(25 \%)$ yang mengalami kecemasan sedang dengan dukungan sosial kurang, Dari hasil uji statistik didapat hasil $\mathrm{p}=0,015$ dengan nilai kemaknaan $\mathrm{p}<0,005$ yang berarti Ho ditolak yang artinya ada hubungan secara signifikan antara dukungan sosial keluarga dengan kecemasan pada lansia di Posyandu Lansia Sedap Malam Krembangan Selatan Surabaya.

\section{Pembahasan \\ 4.1 Dukungan sosial keluarga}

Berdasarkan tabel 3.8 tentang dukungan sosial keluarga tampak bahwa sebagian besar (45\%) responden mendapatkan dukungan sosial keluarga cukup. Menurut Taylor (2003), menyatakan bahwa dukungan sosial yang baik mengacu pada individu tersebut merasa dicintai, diperhatikan, dihargai, bernilai atau bantuan dari orang yang di percaya misalnya 
anggota keluarga (anak, istri, suami dan kerabat). Kepercayaan dan persepsi responden yang cukup dapat berakibat timbulnya anggapan yang baik tentang dukungan sosial keluarga. Jika dikaitkan antara fakta dan teori ada kesamaan. Hal ini jika responden didamping oleh anggota keluarga dan mendapatkan dukungan rasa percaya diri akan bertambah dan motivasi untuk menghadapi masalah yang terjadi akan meningkat sehingga kecemasan yang dialami akan ringan.

Berdasarkan tabel 3.2 tentang karateristik responden sebagian besar responden berpendidikan SD (65\%). Menurut Setiadi (2008), penilaian dukungan sosial keluarga dipengaruhi oleh intelektual yang terdiri dari pengetahuan, pengalaman masa lalu dan pendidikan. Hal ini tidak sesuai antara fakta dan teori dimana fakta menunjukkan dukungan sosial keluarga cukup walaupun responden berpendidikan SD, hal ini bisa terjadi karena lansia masih bisa mempersepsikan dengan baik apa yang telah dilakukan oleh keluarganya, apalagi sebagian besar lansia berada di lingkung keluarganya, jadi walaupun pendidikan rendah lansia masih merasakan adanya dukungan sosial yang cukup dari keluarganya.

Berdasarkan tabel 3.4 tentang karakteristik responden berdasarkan perkerjaan terlihat sebagian besar $(70 \%)$ responden tidak berkerja. Menurut Hawari, (2001) dengan memberi motivasi, semangat dan dorongan agar pasien yang bersangkutan tidak merasa putus asa dan diberi keyakinan serta kepercayaan diri. Perubahan pesikologis yang terjadi pada lansia adalah kehilangan perkerjaan saat tersebut juga dapat menimbulkan stress, terutama jika menyebabkan masalah ekonomi yang berhubungan dengan kesulitan ke uangan. Lansia yang kehilangan pekerjaan akan mengalami penurunan finansial yang mengakibatkan perubahan gaya hidup sehingga lansia mengurangi beberapa aktivitasnya. Dimana dukungan keluarga sangat di butuhkan lansia dalam meningkatkan kualitas hidupnya lebih panjang contohnya seperti Dukungan sosial instrumental yang berupa bantuan secara langsung dan nyata seperti memberi atau meminjamkan uang. Mungkin dengan memberikan peralatan yang dibutuhkan untuk menunjang kegitannya, waktu atau berupa uang. Dengan bantuan finansial dari keluarga tersebut dapat membantu dalam mengurangi stress yang dialaminya. Sebagian diposyandu lansia banyak yang tidak berkerja dan cukup mendapatkan dukungan dari keluarga dikarenakan keluarga masih memberikan kebebasan dalam menunjang gaya hidup lansia yaitu dengan memberikan sebagian penghasilannya kepada lansia, untuk membeli kebutuhan yang dinginkanya seperti sepatu untuk senam sebagai penunjang kesehatannya dalam mengurangi osteoporosis atau nyeri sendi, obat untuk mengura nyeri sendi yang akut.

\subsection{Kecemasan Pada Lansia}

Berdasarkan tabel 3.9 tentang kecemasan sebagian besar $(75 \%)$ responden mengalami kecemasan ringan. Menurut Stuart dan Sundeen (1998) kecemasan yang normal yang memotivasi individu dari hari ke hari sehingga dapat meningkatkan kesadaran individu serta mempertajam perasaannya. Saat peneliti melakukan penelitian di posyandu sedap malam sebagian besar keluarga memperhatikan responden, dan mendengarkan keluh kesahnya. Sehingga timbul kecemasan yang ringan serta dapat mengungkapkannya di keluarga atau cukup dekat hubungan keluarga dengan lansia, adanya waktu luang 
keluarga untuk lansia dengan aktivitasnya yang padat. Sehingga lansia cukup mendapatkan perhatian dari keluarga. Di posyandu sedap malam banyak lansia yang sering menganggap dirinya cukup diperhatikan oleh anggota keluarganya sehingga lansia tingkat kecemasanya ringan.

Berdasarkan tabel 3.5 tentang karateristik responden berdasarkan setatus pernikahan sebagian besar $(70 \%)$ duda atau janda dimana individu sudah kehilangan pasangan hidup. Hal ini sesuai menurut Prasetyono(2007) Dalam doa umat mencari kekuatan yang dapat melipat gandakan yang terbatas dalam diri sendiri dan menciptakan hubungan yang dalam antara manusia dan Tuhan. Dan menurut Priyotni (2012) Kondisi lingkungan sekitar lansia dapat menyebabkan seseorang lebih kuat dalam menghadapi permasalahan dari segi psikososial, berpisah dengan pasangan akan menjadikan individu merasa ketakutan atau khawatir. Hal ini juga terjadi pada responden saat peneliti melakukan penelitian di posyandu sedap malam sebagian besar lansia yang kehilangan pasangan hidup tidak merasakan ketakutan dan kehawatiran. Adanya pendamping oleh keluarga akan mengurangi stress lansia atau beban psikologis yang dirasakan oleh lansia pada tingkat ringan sehingga kecemasan lansia ringan.

Berdasarkan tabel 3.7 tentang karakteristik responde berjenis kelamin (95\%) perempuan memiliki kecemasan yang lebih tinggi. Menurut Stuar (1998) kecemasan terjadi karena adanya konflik yang terjadi antara emosional elemen keperibadian yaitu id, ego dan super ego. Id mewakili insting, super ego mewakili hati nurani, sedangkan ego mewakili konflik yang terjadi antara dua elemen yang bertentangan. kecemasan lebih sering terlihat pada wanita karena wanita sering mengunakan super ego (hati nurani) sehingga sering muncul rasa kecemasan yang berlebihan akibat penyakit atau pesikologis. Sedangkan laki-laki sering mengunakan id (insting) sehingga munculnya rasa kecemasan itu jarang dibandingkan wanita. Hal ini terbukti ketika perempuan memiliki kesempatan untuk mengungkapkan perasaanya ketika mengisi lembar kuisioner yang diberikan peneliti. Lansia sangat antusia dalam mengisi setiap pernyatan sesuai dengan yang dirasakan atau yang dialami lansia. Sehingga hasil yang muncul pada setiap pernyataan mengacu pada perasan kecemasan pada diri lansia.

Berdasarkan tabel 3.1 tentang karakteristik umur responden sebagian besar (45\%) lansia yang berumur 60-65 tahun. Menurut Dr. H. Hadi martono (1994) mengatakan bahwa menua ( menjadi tua) adalah suatu proses menghilangnya secara berlahan kemampuan jaringan untuk memperbaiki diri atau mengganti diri dan mempertahankan struktur dan fungsi normalnya sehingga tidak dapat bertahan terhadap jejas ( termasuk infeksi) dan memperbaiki kerusakan yang di derita. Hal ini sesuai dengan pendapat Ryan dan Austin dalam Friedman, (1998) Pada masa ini lansia baru saja mengalami beberapa perubahan dan kehilangan pasangan hidup yang sudah meninggal dan anak yang sudah meninggalkan rumah untuk hidup sendiri, Secara lebih spesifik, keberadaan dukungan sosial yang adekuat terbukti berhubungan dengan menurunnya mortalitas, lebih mudah sembuh dari sakit dan dikalangan kaum tua, fungsi kognitif, fisik dan kesehatan emosi. saat penelitian di posyandu sedap malam sebagian lansia berumur 60-65 tahun yang mulai mengalami permasalahan perubahan fisik yang mulai terjadi pada dirinya hal ini akan memicu terjadinya kecemasan dikareanakan 
ketidak mampuan lansia dalam mengendalikan perasan ketakutan atau khawatir yang berlebihan, dengan adanya posyandu lansia responden dapat mengalihkan ketakutan dan khawatirannya denga kegiatan senam lansia sehingga tingkat kecemasa ringan.

\subsection{Hubungan antara dukungan sosial keluarga dengan kecemasan lansia pada lansia}

Hubungan antara dukungan sosial keluarga dengan kesepian pada responden berdasarkan uji statistik regresi ordinal didapatkan nilai singnifikasi $(\mathrm{p})=0,015$ yang berarti $\mathrm{HO}$ ditolak atau ada hubungan secara segnifikasi antara dukungan sosial keluarga dengan kecemasan pada lansia diposyandu lansia sedap malam krembangan selatan surabaya. Hasil penelitian ini sesuai teori menurut (Malecki dan Demaray, 2003) Dukungan sosial juga merupakan persepsi seseorang terhadap dukungan yang diberikan orang lain dalam jaringan sosialnya (orang tua, teman dekat, dan sebagainya) yang membantu meningkatkan kemampuan untuk bertahan dari pengaruh-pengaruh yang merugikan. Hal ini berati selama responden mengalami perasaan kecemasan, pada saat itulah dukungan sosial keluarga maka beban psikologis yang dirasakan terasa berat bila ditanggung sendirian akan tetapi jika diceritakan akan terasa ringan. Bila kita melihat tabel tabulasi silang 3.10 tentang dukungan sosial keluarga dengan kecemasan terhadap lansia tampak bahwa 2 responden $(10 \%)$ merasakan kecemasan sedang dengan dukungan sosial keluarga yang kurang. Hal ini dapat dikatakan bahwa responden yang mendapat dukungan keluarga yang kurang akan merasakan kecemasan sedang.

Berdasarkan tabel 3.6 tentang karakteristik status tinggal responden sebagian besar (70\%) responden tinggal bersama keluarga. menurut azizah, (2011) Dukungan Emosional Terdiri dari ekspresi seperti perhatian, empati, dan turut prihatin kepada seseorang. Dukungan ini akan menyebabkan penerima dukungan merasa nyaman, tentram kembali, merasa dimiliki dan dicintai ketika dia mengalami stres, memberi bantuan dalam bentuk semangat, kehangatan personal, dan cinta Berdasarkan penelitian di posyandu sedap malam responden lebih diperhatikan oleh anaknya sebab responden memiliki pendekatan yang baik dari anaknya, responden bisa mengungkapkan keluhanya kepada keluarga sehingga tingkat dukungan keluarga sedang dan kecemasanya ringan.

Berdasarkan tabel 3.3 karakteristik responden berdasarkan jumlah anak (65\%) memiliki anak lebih dari tiga. Hal ini sesuai azizah, (2011) Dukungan Instrumental Merupakan dukungan yang paling sederhana untuk didefinisikan, yaitu dukungan yang berupa bantuan secara langsung dan nyata seperti memberi atau meminjamkan uang atau membantu meringankan tugas orang yang sedang stress. Saat melakukan peneliti di posyandu sedap malam keluarga memberikan dukungan berupa memberikan uang atau dengan membelikan sepatu senam untuk menunjang kegiatanya di posyandu lansia, sehingga dukungan sosial keluarganya cukup dan kecemasan lansia ringan.

\section{Simpulan}

Berdasarkan penelitian yang telah dilakukan maka dapat disimpulkan sebagai berikut :

5.1 Lansia yang berada di Posyandu Lansia Sedap Malam Krembangan Selatan Kelurahan Krembangan Selatan Surabaya sebagian besar memiliki dukungan sosial keluarga cukup. 
5.2 Lansia yang berada di Posyandu Lansia Krembangan Selatan Surabaya kelurahan krembangan selatan kecamatan krembangan selatan Surabaya sebagian mengalami kecemasan ringan.

5.3 Terdapat hubungan antara dukungan sosial keluarga dengan kecemasan pada lansia yang berada di Posyandu Lansia Krembangan Selatan Surabaya kelurahan kecamatan krembangan selatan Surabaya.

\section{Saran}

6.1 Bagi Keluarga

Hendaknya keluarga responden lebih banyak meluangkan waktu bersama untuk serta mengadakan rekreasi keluarga bersama bertujuan agar responden merasa diakui di cintai, keberadaannya, merasa diperhatikan, merasa dihargai, merasa tidak sendiri, memiliki rasa aman, serta memiliki tempat untuk sering berbagai keluh kesah yang dialami sehingga beban psikologis yang dirasakan akan terasa ringan.

\subsection{Bagi Posyandu Lansia Krembangan}

Diharapkan posyandu tetap mengadakan kegiatan yang bersifat sosial yang juga dapat meningkatkan keakraban diantara lansia itu sendiri diharap kader posyandu dapat kerjasama dengan keluarga dan petugas kesehatan dalam upaya meminimalkan kecemasan pada lansia melalui dukungan sosial keluarga (system support), memberikan pendidikan kesehatan.

\subsection{Bagi Institusi Pendidikan}

Diharapkan institusi pendidikan turut serta dalam membantu meningkatkan kepedulian keluarga dalam melakukan perawatan pada lansia dengan memberikan penyuluhan kesehatan untuk mengurangi permasalahan psikologis terutama masalah kecemasan bagi lansia.
6.4 Bagi peneliti selanjutnya

Diharapkan penelitian selanjutnya dapat menjadi sebagai acuan dan gambaran untuk mengembangkan kondisi yang sama dan sampel representatif.

\section{DAFTAR PUSTAKA}

Ahmad Jubaedi, 2008. Mengenal Usia Lanjut Dan Perawatannya. Jakarta: Salemba Medika.

Abu Ahmadi, H. 2009. Psikologis Sosial. Jakarta: Rineka.

Baron, R. A \& Bryne, D (2005). Psikologi Sosial. Jilid II. Edisi kesepuluh. Jakarta: Erlangga.

Deaux, Dane \& Wrightsman, S. (1993). Social Psychology in the 90's $\left(2^{\text {nd }}\right.$ Edition). California: Wadsworth Publishing Company Ine.

Djarwanto Ps. SE. (2001). Mengenal Beberapa Uji Statistik Dalam Penelitian. Yogyakarta: liberty Yogyakarta.

Fridman, Marylin M. (2009). Keperawatan Keluarga: Teori Dan Praktek Edisi 6. Jakarta: EGC.

Gunarsah Singgih D. (2005). Dari Anak Sampai Usia Lanjut: Bunga Rampai Psikologi Anak. Jakarta: BPK Gunung Mulia.

Hurlock, E. B. (1999). Psikologi Perkembangan: Suatu Pendekatan Sepanjang Rentang Kehidupan Edisi Kelima. Jakarta: Erlangga.

Mass Meridean L. (2011). Asuhan Keperawatan Geriatrik: Diagnosa 
NANDA Kriteria Hasil NOC Intervensi NIC. Jakarta: EGC.

Notoatmojo, Soekidjo. (2000). PrinsipPrinsip Penelitian Kesehatan. Jakarta: Rineka Cipta.

(2001). Metodologi

Penelitian Kesehatan. Jakarta: Rineka Cipta.

Nursalam. (2000). Metodologi Riset Keperawatan. Jakarta: CV Sagung Seto.

(2001). Pendekatan Praktisi Metodologi Riset Keperawatan. Jakarta: CV. Sagung Seto.

.(2003). Konsep Penerapan Metodologi Penelitian Ilmu Keperawatan: Pedoman Skripsi, Tesis. Dan Istrumen Penelitian Keperawatan.Edisi I. Jakarta : Salemba Medika. .(2003). Konsep Penerapan Metodologi Penelitian Ilmu Keperawatan: Pedoman Skripsi, Tesis. Dan Istrumen Penelitian Keperawatan.Edisi II. Jakarta : Salemba Medika.

Nugroho H. Wahyudi. (2008). Keperawatan Gerontik \& Geriatrik. Edisi 3. Jakarta : EGC

Priyanto, 2015. Nursing Intervention Classification NIC Dalam Keperawatan Gerontik. Jakarta:Salemba Medika

Safarino, EP.(2006). Healt Psychology Biopsychosocial Interaction. USA. John Willey and Sons.
Santrok, J. W. (2006). Perkembangan Masa Hidup : Edisi 5. (Terjemahan Juda Damalik \& Achmad Chusair). Jakarta : UI Perss

Siti Maryam R. (2008). Mengenal Usia Lanjut dan Perawatannya. Jakarta: Salemba Medika.

Sulaiman, Wahid. (2004). Analisa Regrasi Mengunakan SPSS Contoh Kasus Dan Pemecahan. Yogyakarta : Andi

Utami Putri A.(2014). Hubungan Dukungan Keluarga Dengan Tingkat Kecemasan Lansi Yang Dilakukan HOME CARE Di Wilayah Kerja Rumah Sakit Raja Wali Citra Bantu Tapal Bnatul http://www.stikessuryaglobal.ac.id/.../j urnal/.../ika\%20ayu.volume\%208\%20 20 Tanggal Akses : 08-02-2020.

Kail and Cavanaug, (2010).Pengertian Dukungan Sosial. Sumantra Selatan. http://repository.usu.ac.id/bitstream/123456 789/52134/4/Chapter II.pd

Tanggal Akses : 12-02-2020

voltaren, (2017). Mengenali Nyeri Sendi

Dan Jenis-Jenisnya. Gsk

http://www.voltaren.co.id/memahami nyeri /tentang-nyeri-sendi.html

Tanggal Akses : 13-02-2020 